Original Research Paper

\title{
Reliability Analysis of Rotary Kiln A
}

\author{
Agustina Hotma Uli Tumanggor ${ }^{1}$, Muhammad Rizky Ikhsan', Setyo Yulio Pratama² \\ ${ }^{1}$ Program Studi Teknik Industri, Fakultas Sains dan Teknologi, Universitas Sari \\ Mulia. Banjarmasin, Indonesia. \\ ${ }^{2}$ Program Studi Teknik Mesin, Fakultas Teknik, Universitas Lambung Mangkurat. \\ Banjarmasin, Indonesia.
}

Article History

Received:

01.10 .2020

Revised:

25.10 .2020

Accepted:

29.01.2021

*Corresponding Author: Agustina Tumanggor Uli T. Email:

agustina.hotma@gmail.com

This is an open access article, licensed under: $\mathrm{CC}-\mathrm{BY}-\mathrm{SA}$
Abstract: Rotary Kiln as a pyroprocessing device is used to raise the temperature of the material to a high temperature (calcination) in a continuous process. By looking at the constraints on PT. Meratus Jaya Iron \& Steel, whose production machines often have breakdowns, is a fundamental reason for researchers to increase the reliability level of PT. Meratus Jaya Iron \& Steel. The research was conducted on the Rotary Kiln Machine made in Germany which plays a high enough role in the company. The method used is the Reliability with Mean Time to Repair Method (MTTR). From the results of calculations of Reliability with MTTR on Rotary Kiln A is Reliability at the time of 296 hours operation results obtained by 0.5371 and MTTR 537.7732. The higher the reliability value, the better the machine used in the operation process.

Keyword: Industrial Maintenance System, Reliability, Weibull Distribution. 


\section{Introduction}

In the industrial world, the product is the main result of a production process that forms a production process system. The production process system consists of input, operation process, and output. A production process system can continue to run, requiring maintenance activities (maintenance) of production equipment and machines. Maintenance defined as a plant facility maintenance activities as well as holding repair, adjustment, or replacement is required in order for an operating state in accordance with the planned production [1].

This can be achieved by reducing congestion or constraints as small as possible so that the system can work efficiently. But often what happens is negligence and maintenance is only remembered when the damage has occurred in the production system which causes additional maintenance costs. However, if the maintenance is carried out thoroughly and regularly, it will be useful to ensure the continuity of the production process and the life of the production facility.

PT. Meratus Jaya Iron \& Steel is a company engaged in the production of iron ore into semifinished products (Iron Reduction Kiln / IRK). For companies, machines have a very important and vital role to support the production process. Because almost all of the production processes that take place use machines. Any damage or disruption to the production machine can cause the production process to stop. Therefore, well-planned and well-planned maintenance are very important so that the production process runs smoothly, because as we all know that damage to machines or production equipment is something that cannot be avoided.

The research was conducted on the Rotary Kiln Machine made in Germany which has a high role in the company. Rotary Kiln is a place for the reduction of iron ore which results is called an iron reduction kiln or commonly known as sponge iron. The choice of research at the Rotary Kiln is because the production machines often have problems or problems. Based on the above problems, the researchers wrote the title of the final project entitled Reliability Analysis (Reliability) Rotary Kiln A (Case Study: PT. Meratus Jaya Iron \& Steel).

\section{Literature Review}

\subsection{Maintenance System}

Machine maintenance activities are an integral part of production activities [2]. Maintenance activities have a very big influence on the smooth running of the factory [3]. Maintenance objectives are achieved in a factory or industry not only supported by maintenance facilities and techniques but also influenced by a management system applied.

Maintenance is a concept of all the activities required to maintain or maintain the quality of the equipment so that it can function properly as in the previous condition. Choosing the right maintenance strategy can increase readiness and reliability and decrease the rate of breakdown of facilities and machines. Maintenance is an activity undertaken to maintain or improve each facility so that in a state that is acceptable by the standards prevailing at a reasonable cost level [4].

Treatment objectives are as follows [5]:

a. Maximizing production at the lowest cost, highest quality, and optimum safety standards.

b. Identity and application fees.

c. Gather information about the cost of necessary maintenance.

d. Provide accurate maintenance recording data.

e. Optimizing maintenance resources.

f. Minimizes energy use.

g. Minimizing the availability of spare parts in the warehouse.

\subsection{Theory of Reliability}

Treatment components or equipment can not be separated from the discussion regarding reliability (Reliability). As well as reliability is one measure of the success of the maintenance system, reliability is also used to determine the maintenance schedule itself. Recently, the concept of reliability is also used in various industries, for example in determining the number of spare parts in the maintenance and maintenance schedule.

The measure of the success of a treatment action can be expressed by the level of reliability. In general, reliability can be defined as the probability that a system or product can operate properly without experiencing damage under certain conditions and a predetermined time [2] [5] [6] [7]. 
Based on the definition of reliability, it is divided into five main components, namely:

a. Probability

It is the first principal component, a numerical input for the Reliability Assessment of a system which is also a quantitative index to assess the viability of a system. Indicates that Reliability states that the probability is $0-1$.

b. Expected capabilities (Satisfactory Performance)

This component provides a specific sign that the criteria in determining the level of satisfaction must be clearly described. For each unit, there is a standard to determine what is meant in the expected ability.

c. The desired goal

The intended purpose, where the use of the equipment must be specific. This is due to several levels in producing a consumer product.

d. Time

Time is a part that is related to the system performance level so that it can determine a schedule in the Reliability function. The time used is MTBF (Mean Time between Failures), MTTF (Mean Time to Failure), and MTTR (Mean Time to Repair).

e. Operating Conditions (Specified Operating Condition)

Factors - environmental factors such as vibration (vibration), inertia (humidity), the geographical location of which is a condition where the course of the operation, it is included this condition. Factors not only addressed to the conditions for a certain period of time when the system or product being process, but also when the system or product is in the warehouse (storage) or moving (transformed) from one location to another.

\subsection{Benefit of Reliability}

The main objective of a reliability study is to provide information as a basis for making decisions. In addition, the theory of reliability can be used to predict when a spare part on a machine is damaged, so that it can determine the level of production machine spare parts inventory.

Checks are used to find out whether the system is still in a state that meets the desired conditions or not. Can schedule repairs to components before breakdowns occur.

\subsection{Method of Analysis}

In the Reliability theory, there are two methods of analysis

a. Qualitative Analysis Methods

The analysis method is based on past experience.

b. Quantitative Analysis Methods

The method of analysis is done by calculation, the calculation can be in the form of statistics.

\subsection{Reliability Distribution Pattern}

In determining the reliability of a component, the factors that can be interrelated are the damage rate and time. The following is the relationship between the rates of destruction of the reliability such as Figure 1.

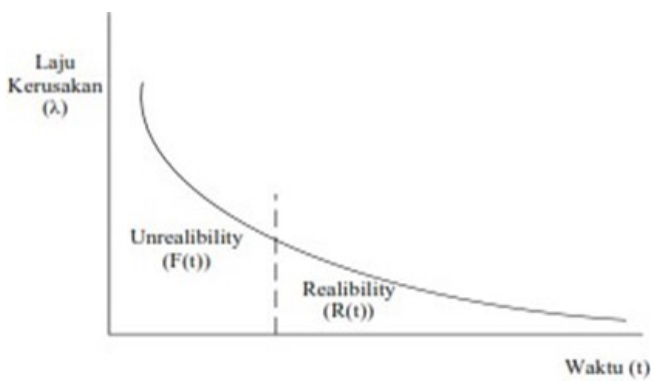

Figure 1. Reliability Curve [8] [9] 
Based on the Figure 1, it is explained that it is said to be unreliability if a tool or machine with a high rate of damage with a shorter operating time. The unit of failure rate is failure per time. If the failure is high and the operating time of a device is low, it is said to be unreliability. Told reliability if the level of damage is small and the time in process longer tool. In here what if the failure of a small device at a longer operating time.

Researchers use the Weibull Distribution because the Weibull Distribution was created specifically for determining life. Based on this it is assumed that the appropriate distribution is the Weibull distribution. Weibull is a simple empirical distribution that represents actual data. This distribution is commonly used in describing the characteristics of component damage.

The functions of the Weibull distribution are as follows [10] [11] [12] [13] [14] [15]:

a. $\operatorname{CDF}($ Cumulative Distribution Function)

The cumulative distribution function or the cumulative distribution function is a function that adds up the probability value until a certain event as it is known that the number of likelihood values is 1 . The use of CDF is to find out the probability (probability) in a random experiment. CDF has conditions, namely $0 \leq \mathrm{F}(\mathrm{t}) \leq 1$ and $\mathrm{F}(\mathrm{t})$ is a non-decreasing function (the function of the data is not monotonous / the data is random) as for The CDF function, which is as follows:

$F(t)=1-e^{-\left(\frac{t}{6}\right)^{\beta}}$

$$
\begin{aligned}
& F(\mathrm{t})=\text { Cumulative Distribution Function (\%) } \\
& t \quad=\text { time (hour) } \\
& \theta \quad=\text { Shape Parameters of the Weibull Distribution } \\
& \beta=\text { Scale Parameter of Weibull Distribution }
\end{aligned}
$$

b. Reliability

The reliability function $R(t)$ is a reliability function to determine which system components or sub-systems are running according to their capabilities at a certain time. The functions of reliability, namely:

$$
\begin{array}{ll}
R(t) & =e^{-\left(\frac{t}{\theta}\right)^{\beta}} \\
R(\mathrm{t}) & =\text { Reliability (\%) } \\
t & =\text { time (hour) } \\
\theta & =\text { Shape Parameters of the Weibull Distribution } \\
\beta & =\text { Scale Parameter of Weibull Distribution }
\end{array}
$$

c. Failure Rate

The failure rate or the level of damage is the main requirement of an item or subsystem component which at certain intervals will fail. The function of the failure rate is:

$$
\begin{array}{ll}
h(t) & =\frac{\beta}{\theta}\left(\frac{t}{\theta}\right)^{\beta-1} \\
h(t) & =\text { failure rate } \\
t & =\text { time (hour) } \\
\theta & =\text { Shape Parameters of the Weibull Distribution } \\
\beta & =\text { Scale Parameter of Weibull Distribution }
\end{array}
$$

d. Mean

The average lifetime value can be taken from the Weibull distribution using the following function.

$$
\begin{aligned}
& E(t)=\theta \Gamma\left(1+\frac{1}{\beta}\right) \\
& E(\mathrm{t})=\text { average life (hour) } \\
& t \quad=\text { time (hour) }
\end{aligned}
$$


$\theta \quad=$ Shape Parameters of the Weibull Distribution

$\beta \quad=$ Scale Parameter of Weibull Distribution

$\Gamma \quad=$ Gamma function, taken from the Gamma Function Table

e. Mean Time to Repair (MTTR)

The average repair time (MTTR) is the average time a component undergoes repairs. MTTR is the time used for repair time. MTTR for Weibull distributed data is expressed in the following equation:

$$
\begin{aligned}
& \text { MTTR }=\theta \cdot \Gamma\left(1+\frac{1}{\beta}\right) \\
& M T T R=\text { average life (hour) } \\
& \begin{array}{ll}
t \quad & =\text { time (hour) } \\
\theta \quad & =\text { Shape Parameters of the Weibull Distribution } \\
\beta \quad & =\text { Scale Parameter of Weibull Distribution } \\
\Gamma \quad & =\text { Gamma function, taken from the Gamma function table }
\end{array}
\end{aligned}
$$

\section{Methodology}

The steps taken in the study are shown in Figure 2. Starting from the beginning of the survey, then the termination of the subject matter supported from field studies and literature, continue troubleshooting purposes of the issues that have been taken, then the data collection, namely engine operating data Rotary Kiln, Rotary Kiln repair data, from data collection continued with data processing carried out by making a Pareto diagram, continued by making the Weibull distribution and the distribution results were calculated and obtained the data results using the Minitab 17.0 software. The results of data processing are then analyzed on how to solve the problem. After completion, conclusions and suggestions are drawn.

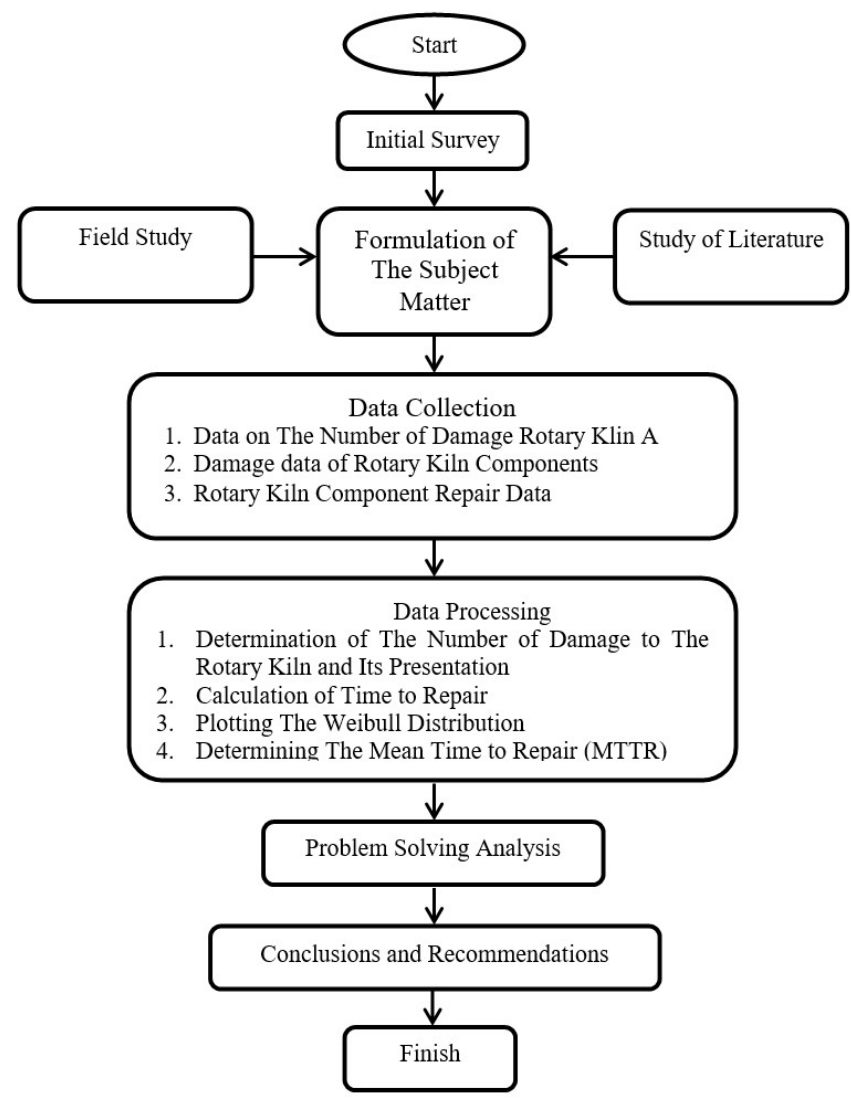

Figure 2. Research Methods 


\section{Finding and Discussion}

\subsection{Rotary Kiln Data Processing A}

The following are the types of damage and frequency of damage to the Rotary Kiln A classed can be seen in Table 1. Research retrieve data on the production period from August 2013 to June 2014.

Table 1. Types of Damage and Frequency of Damage to Rotary Kiln A

\begin{tabular}{ccc}
\hline No & Damage Data & Frequency \\
\hline 1 & cleaning transfer chute and accretion & 1 \\
\hline 2 & cleaning transfer chute and accretion & 1 \\
\hline 3 & cleaning border and accession & 1 \\
\hline 4 & cleaning border and accession & 1 \\
\hline 5 & cleaning border and accession & 1 \\
\hline 6 & cleaning border and accession & 1 \\
\hline 7 & cleaning border and accession & 1 \\
\hline 8 & cleaning border and accession & 1 \\
\hline 9 & cleaning border and accession & 1 \\
\hline 10 & cleaning border and accession &
\end{tabular}

Based on the data on the types of damage and the frequency above, it can be processed into a Pareto diagram as shown in Figure 3.

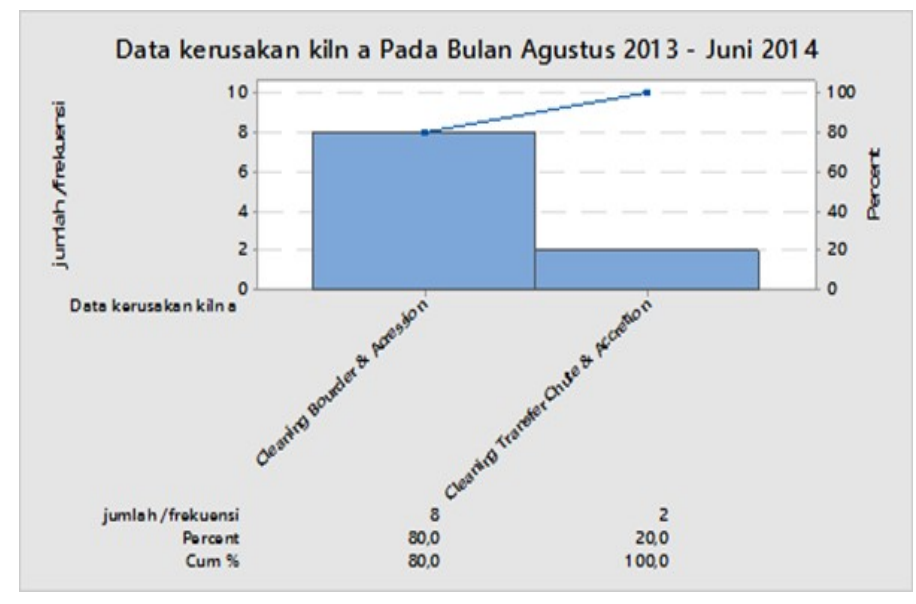

Figure 3. Pareto Rotary Kiln A

The following is the Rotary Kiln A repair data can be seen in Table 2 which is as follows:

Table 2. Types of Damage and Frequency of Damage to Rotary Kiln A

\begin{tabular}{ccc}
\hline \multicolumn{3}{c}{ Data Time to Repair Rotary Kiln A (hours) } \\
\hline 313 & 744 & 744 \\
\hline 164 & 616 & 394 \\
\hline 392 & 532 & \\
\hline 744 & 720 & \\
\hline
\end{tabular}


The Weibull distribution plot on Time to Repair data is shown in Figure 4 which is as follows:

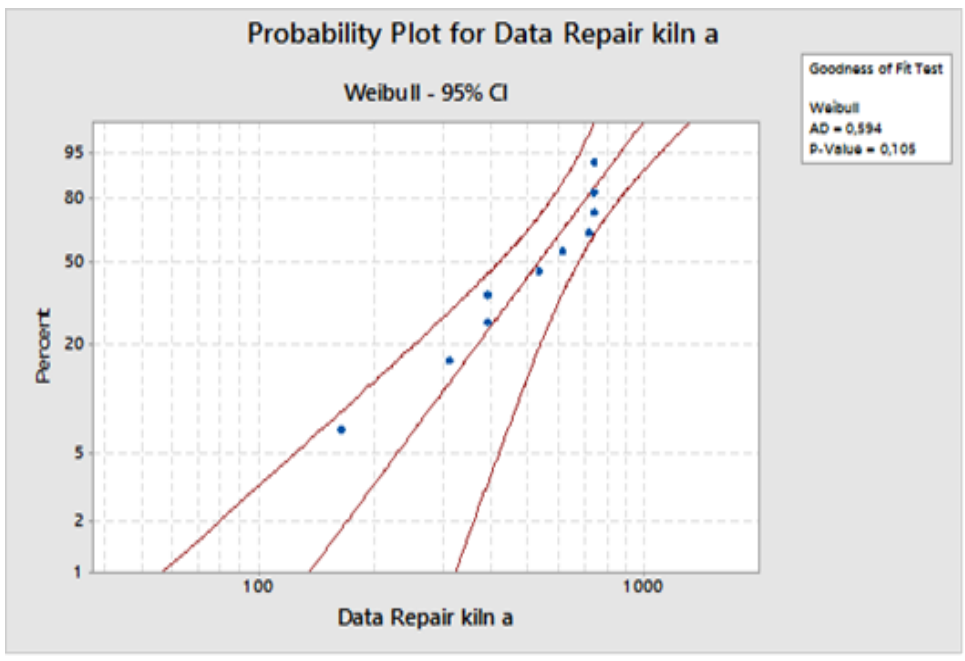

Figure 4. Weibull Distribution Plot

Since the p-value of the Weibull Distribution from the results of the Minitab 17.0 software is 0.105 , which is greater than $\alpha$ value (which is set at 0.05 ), it can be concluded that the Weibull distribution can be used as a representation of the data group.

To determine the Weibull distribution parameters by looking at the Identification Distribution of the results of 17.0 Minitab Software is shown in the following Figure 5.

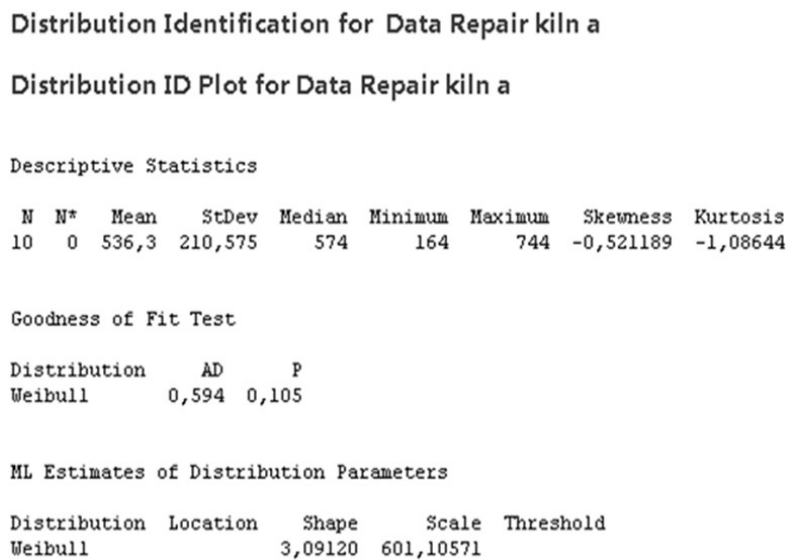

Figure 5. Identification Distribution

Based on the Figure 5, it can be seen that the scale parameter value $\theta=601.10571$ and the shape parameter value $\beta=3.09120$ from the Time to Repair data. After the parameters $\theta$ and $\beta$ continue with the MTTR calculation at Rotary Kiln A, which is as follows:

$\operatorname{MTTR}=\theta \cdot \Gamma(1+1 / \beta)$

MTTR $=601.10571 . \Gamma(1+1 / 3.09120)$

$\mathrm{MTTR}=601.10571 * \Gamma(1.323499) \mathrm{MTTR}=601.10571 *(0.89464)$

$\mathrm{MTTR}=537.7732$ hour

Based on the MTTR calculation of the Rotary Kiln A, the result is 537.7732 hours. 
The following is the lifetime data for the Rotary Kiln A for a machine can be seen in Table 3, which is as follows:

Table 3. Data Life Time Rotary Kiln A

\begin{tabular}{|c|c|c|}
\hline No & Machine Name & $\begin{array}{c}\text { Life Time } \\
\text { (cycle) }\end{array}$ \\
\hline 1 & Rotary Kiln A & 386 \\
\hline 2 & Rotary Kiln A & 556 \\
\hline 3 & Rotary Kiln A & 459 \\
\hline 4 & Rotary Kiln A & 328 \\
\hline 5 & Rotary Kiln A & 56 \\
\hline 6 & Rotary Kiln A & 212 \\
\hline
\end{tabular}

The plot of the Weibull Distribution on the Life Time data is shown in Figure 6.

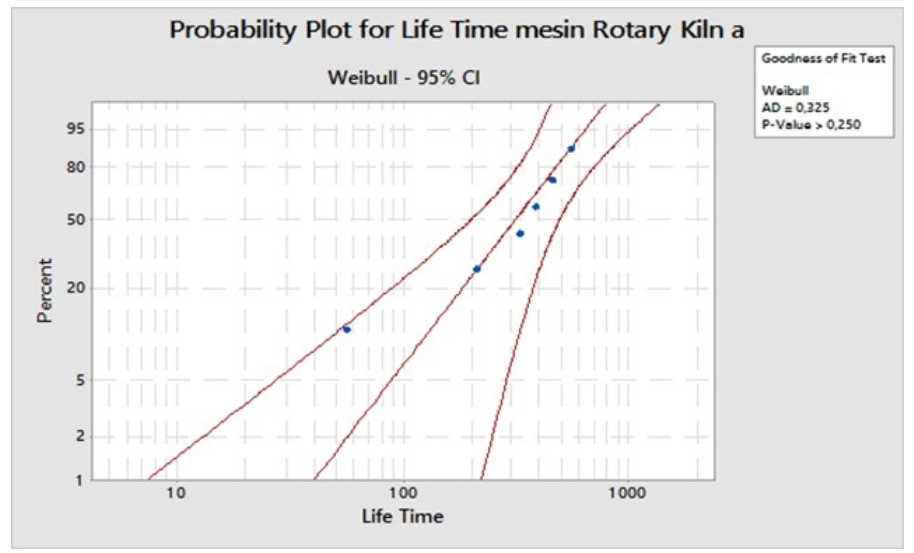

Figure 6. Weibull Distribution Plot

Since the p-value of the Weibull Distribution from the results of the Minitab 17.0 software, the result is $>0.250$ greater than the $\alpha$ value (which is set at 0.05 ), it can be concluded that the Weibull distribution can be used as a representation of the data group.

To determine the Weibull distribution parameters by looking at the Identification Distribution of the results of the Minitab 17.0, it is shown in the Figure 7.

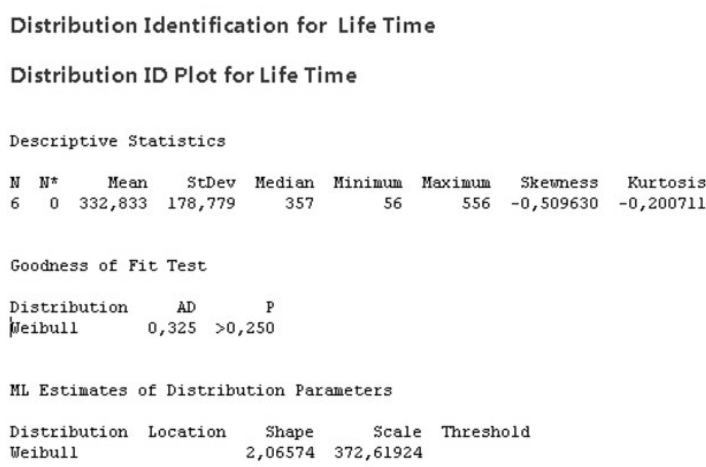

Figure 7. Identification Distribution 
Based on Figure 7, it can be seen that the scale parameter value $\theta=372.61924$ and the shape parameter value $\beta=2.06574$ from the Life Time data. After the parameters $\theta$ and $\beta$ are continued with the calculation of CDF, Reliability, Failure Rate, Mean on Rotary Kiln A, which are as follows:

a. CDF (Cumulative Distribution Function)

Researchers took the operating time interval or the life time of the Rotary Kiln, namely the average time of the two Rotary Kilns of 296 hours.

$$
\begin{aligned}
& F(l)-1-e^{-\left(\frac{t}{6}\right)^{\beta}} \\
& F(t)=1-e^{-\left(\frac{296}{872,61924}\right)^{2,06574}} \\
& F(\mathrm{t})=1-0,5371 \\
& F(\mathrm{t})=0,4629
\end{aligned}
$$

From the results of the CDF calculation on the Rotary Kiln A, the percentage of damage is 0.4629 $(46.29 \%)$.

b. Reliability

Researchers took the time gap berop e constellation or a life time Rotary Kiln ie with an average time of 296 hours.

$$
\begin{aligned}
& R(t)=e^{-\left(\frac{t}{6}\right)^{\beta}} \\
& R(t)=e^{-\left(\frac{395}{872,61524}\right)^{1,000574}} \\
& R(t)=0,5371
\end{aligned}
$$

From the results of calculating the Reliability at Rotary Kiln A, the result is $0.5371(53.71 \%)$ hours.

c. Failure Rate

Researchers took the operating time interval or the lifetime of the Rotary Kiln with an average time of two Rotary Kiln A of 296 hours.

$$
\begin{aligned}
& h(t)=\frac{R}{\theta}\left(\frac{t}{\theta}\right)^{\beta-1} \\
& h(t)=\frac{2,06574}{372,61924}\left(\frac{296}{372,61924}\right)^{2,06574-1} \\
& h(t)=0,00554(0,7944)^{1,06574} \\
& h(t)=0,00554(0,7825) \\
& h(t)=0,00434
\end{aligned}
$$

From the calculation of Failure Rate on Rotary Kiln A, the results are 0.00434 failures/hour.

d. Mean

Furthermore, the calculation of the mean (average life of the Rotary Kiln A for a machine) is calculated as follows:

$$
\begin{aligned}
& E(t)=\theta \cdot \Gamma\left(1+\frac{1}{\beta}\right) \\
& E(t)=372,6194 \cdot \Gamma\left(1+\frac{1}{2,06574}\right) \\
& E(t)=372,6194 . \Gamma(1,48) \\
& E(t)=372,6194 x 0,88575 \\
& E(t)=330,0475
\end{aligned}
$$

From the calculation of the mean on Rotary Kiln A, the results are 330.0475 hours. 


\subsection{Analysis}

Based on the result, the CDF was 0.4629. This shows that the CDF value is relatively small, the smaller the CDF value, the smaller the percentage of equipment damage will be.

If the CDF value is small, the reliability level will be greater, with the Rotary Kiln engine reliability level of 0.5371 . If the value of reliability will be smaller high failure rate (Failure Rate) which will take place on the appliance.

The failure rate for Rotary Kiln A was 0.00434 at 296 hours of operation. With a high level of reliability and a small failure rate, the higher the average Rotary Kiln A machine can live with a mean value of 330.0475 .

It can be said, if the reliability of the machine high and low failure rate with an average machine lifetime then when Rotary Kiln the case of failure the average level of improvement Rotary Kiln A will be higher. With the average value of repair of the Rotary Kiln machine of 537.7732 hours according to the level of damage/weight of damage that is categorized as heavy or moderate or light.

\subsection{Company Regulations}

Based on the research that has been done, researchers can provide input to the company concerned. Component Rotary Kiln A should be checked every day, but in actual preventive care, Rotary Kiln A to be checked every 10 days based on the ni lai average Rotary Kiln A. From the problems with the Rotary Feeder, the damage that often occurs is blockages in the Rotary Feeder. The solution that we can do is to clear the clogs by crushing the clumped coal on the rotary feeder. From the problem with the Lobe Compressor, the damage that often occurs is the contamination of the solution filter, which we can do by cleaning the filter using a brush. Of the problems on Kiln Shell damage that often occurs is a blockage in the outlet Kiln (accretion) solutions can we do to do the inspection on Thermocouple is the same between in the actual DCS (Distributed Control System).

Of the problems in the Kiln Inlet Seal damage that often occurs is fouling Kiln Inlet Seal solutions can we do with examination on the seal so that the lubrication between Kiln Shell and Dust settling Chamber went smoothly. From the problems in the kiln outlet seal, the damage that often occurs is the contamination of the Kiln Outlet Seal, the solution that we can do is by checking the seal so that the lubrication between the Kiln Shell and Chute transfers runs smoothly. Of the problems at Shell Air Fan damage that often occurs is fouling the blade Fan solutions can we do to do the cleaning on the blade Shell Air Fan. Also carried out measurements of airflow between the DCS and the actual. Of the problems on Thermocouple damage that often occurs ie error sensor solutions that we can do with the calibration Thermocouple. Also carried out temperature measurements between the DCS and the actual.

\section{Conclusion}

From the research results, it can be concluded:

a. The main factor in the reliability value is the use of the machine, if this machine is used for a longer time, the reliability value will be smaller or closer to 0 . This is evident from the service life of Rotary Kiln A.

b. The MTTR value of Rotary Kiln A is large because the frequency of damage to Rotary Kiln A is the heaviest damage weight, namely cleaning boulder \& accession with the highest frequency of damage. So it is appropriate if Rotary Kiln A has a relatively longer repair time.

\section{References}

[1] S. Assauri, Manajemen Produksi dan Operasi, Edisi 4. Jakarta: Fakultas Ekonomi Universitas Indonesia, 1993.

[2] S. Assauri, Manajemen Produksi dan Operasi, Edisi Revisi. Jakarta: Fakultas Ekonomi, Universitas Indonesia, 1998.

[3] V. Gasperz, Analisis Sistem Terapan Berdasarkan Pendekatan Teknik Industri. Edisi Pertama, Bandung: Tarsito, 1992.

[4] Supandi, Manajemen Perawatan Industri. Bandung: Ganeca Exact.

[5] T. Wireman, World Class Maintenance Management, 1st Ed. New York: Industrial Press, 1988.

[6] H. Handoko, Dasar- Dasar Manajemen Produksi dan Operasi. Jakarta: BPFE, 2019. 
[7] B. I. Harnadi, and R. A. Z. Darmawan, Perencanaan Pemeliharaan Mesin Produksi Dengan Menggunakan Metode Reliability Centred Maintenance (RCM) II Pada Mesin Blowing OM," Unpublished thesis. Jakarta: Fakultas Teknik, Universitas Bina Nusantara, 2014.

[8] P. Gopalakrishnan, and A. K. Banerji, Maintenance and Spare Parts Managements. NewDelhi: Prentice Hall, 2004.

[9] PT. Meratus Jaya Iron and Steel, Operating \& Maintenance Manual Book of Rotary Kiln Jilid 1. Batulicin: PT. Meratus Jaya Iron and Steel, 2008.

[10] S. B. Abbas, E. Steven, H. Christian, and T. Sumanto, "Penjadwalan Preventive Maintenace Mesin B. Flute Pada PT AMW Jurusan Teknik Industri," Unpublished thesis. Jakarta: Fakultas Teknik, Universitas Bina Nusantara, 2018.

[11] A. Sachbudi, and S. Andy, "Analisa Keandalan Komponen Kritis Lift NPX-36000 Untuk Menentukan Jadwal Perawatan Pencegahan Yang Optimum," Unpublished thesis. Jakarta: Fakultas Teknik, Universitas Bina Nusantara, 2013.

[12] G. Yusfiq, "Penerapan Sistem Perawatan Menggunakan Metode Reliability Centred Maintenace (RCM) Pada Mesin Loom LSL-4 (Studi Kasus: PT. Dasaplast Nusantara)," Unpublished thesis. Jakarta: Fakultas Teknik, Universitas Bina Nusantara, 2014.

[13] A. Candra, "Optimasi Preventif Maintenance Menggunakan Metode Reliability Centered Maintennace," Teknologi: Jurnal Ilmiah dan Teknologi, vol. 2, no. 2, pp.112-120, 2020.

[14] T. H. Ardhi, "Minimasi Downtime Pada Unit Shore To Ship Dengan Metode Reliability Centered Maintenance (RCM) di PT. Mitra Sentosa Abadi," JISI: Jurnal Integrasi Sistem Industri, vol. 6, no. 2, pp.127-133, 2019.

[15] W. H. Afiva, F. T. D. Atmaji, and J. Alhilman, "Usulan Interval Preventive Maintenance dan Estimasi Biaya Pemeliharaan Menggunakan Metode Reliability Centered Maintenance dan FMECA," Jurnal Ilmiah Teknik Industri, vol. 18, no. 2, pp. 213-223, 2019. 